\title{
Coexistence of Behçet's Disease and Ankylosing Spondylitis: A Case Report
}

\author{
Ankilozan Spondilit ve Behçet Hastaliğinin Birlikteliği: Bir Olgu Sunumu
}

\author{
Hikmet Koçyiğit' ${ }^{2}$, Yasemin Turan¹, Korhan Bayram², Alev Gurgan², Hülya Deveci², Anıl Güvenç² \\ ${ }^{1}$ Adnan Menderes Üniversitesi Tıp Fakültesi, Fiziksel Tıp ve Rehabilitasyon Anabilim Dalı, Aydın, Turkey \\ 2izmir Atatürk Eğitim ve Araştırma Hastanesi, Fiziksel Tıp ve Rehabilitasyon Kliniği, İzmir, Turkey
}

\begin{abstract}
Although overlap syndrome is frequently encountered in rheumatology practice, only a few cases of coexisting Behçet's disease and ankylosing spondylitis have been reported in the literature. Thus, in this article, we aimed to present a 55 -year-old male patient with coexisting Behçet's disease and ankylosing spondylitis who had HLA-B5 positivity, HLA-B27 negativity, and oral and genital lesions. (Turk J Rheumatol 2010; 25: 217-20) Key words: Ankylosing spondylitis, behçet's disease
\end{abstract}

Received: 06.10.2008

Accepted: 29.01.2009

\section{Özet}

Romatolojik hastalıklarda çakıșma sendromlu hastalara sıklıkla rastlanılmakla birlikte, Behcet hastalığı ve ankilozan spondilit hastalığının birlikteliği olan az sayıda olgu vardır. Bu sebeple, biz bu makalede Behçet hastalığı ve ankilozan spondilit birlikteliği olan HLA B5 pozitifliği, HLA B27'nin negatif olduğu, oral ve genital bölgede lezyonları bulunan 55 yașındaki erkek hastayı literatürler eșliğinde sunmayı amaçladık.

(Turk J Rheumatol 2010; 25: 217-20)

Anahtar sözcükler: Ankilozan spondilit, behçet hastalığı

Alındığı Tarih: 06.10.2008 Kabul Tarihi: 29.01.2009

\section{Introduction}

Behçet's disease (BD) is a multi-system disease characterized by a triple symptom complex consisting of genital ulcer, aphthous stomatitis and iritis, frequently accompanied by vasculitis (1). Sacroiliitis is reported frequently in BD (2). BD has been previously considered to be a subgroup of seronegative spondyloarthritis (SpA). Although BD was reported to have a strong association with HLA-B51 rather than with B27, it was concluded that it is not a subgroup of the seronegative $\operatorname{SpA}(2)$. On the other hand, the number of reported cases of coexisting BD and ankylosing spondylitis (AS) has increased (3-9). Recent reports showed that proinflammatory cytokines such as tumor necrosis factor (TNF) -alpha and genetic factors play important roles in the pathogenesis of both diseases (10-13).

In this article, we aimed to present a 55-year-old male patient with coexisting BD and AS who had HLA-B5 positivity, HLA-B27 negativity and oral and genital lesions.

\section{Case Presentation}

A 55-year-old male admitted to our outpatient clinic with complaints of neck, low back, hip and knee pain, morning stiffness lasting two hours, and oral and genital ulcers. He described recurrent, painful and ulcerated oral (three times a month) and genital (once a month) lesions for 25 years. He had also suffered from migrating arthritis of both knees during the last 15 years. The diagnosis of BD had been made 10 years before after detection of his lesions, similar to erythema nodosum, on the anterior of both lower extremities, and colchicine treatment $(1.5 \mathrm{mg} /$ day) had been initiated. However, the patient could not continue this treatment for socioeconomic reasons. Skeletal muscle complaints including limitation of neck, low back and hip movements, night pain, and morning stiffness lasting two hours had not been attributed to any disease in the last two years. He did not specify any rheumatic disease in his family history.

On physical examination, five oral aphthous ulcers (Figure 1) and two genital ulcerative lesions were observed. A spine examination revealed marked limitation

Address for Correspondence: Dr. Yasemin Turan, Adnan Menderes Üniversitesi Tıp Fakültesi, Fiziksel Tıp ve Rehabilitasyon Anabilim Dalı, Aydın, Turkey Phone: +902564441256E-mail: yasemin_dincer@yahoo.com doi: $10.5152 /$ tjr. 2010.32 
of both the cervical and low back. Thoracic kyphosis was increased. Measurements such as modified lumbar Schober, dorsal Schober and chest expansion were found to be $4 \mathrm{~cm}, 1 \mathrm{~cm}$, and $1.5 \mathrm{~cm}$, respectively. Movement in both hips was limited and painful. Bilateral knee movements were painful, but arthritis was not observed. He did not describe any conjunctivitis, urethritis, psoriasis, severe diarrhea attacks, or cardiovascular or neurological symptoms in his personal history. The Bath disease activity score (BASDAI) used in AS was measured as 5.2. Peripheral pulses were palpable. The skin pathergy test was negative. Ophthalmologic and neurological examinations were considered to be normal.

Laboratory evaluation revealed erythrocyte sedimentation rate (ESR) of $112 \mathrm{~mm} / \mathrm{hr}$ and C-reactive protein (CRP) of $16.75 \mathrm{mg} / \mathrm{L}$ (normal <5 mg/L), and rheumatoid factor was negative. Routine laboratory tests, complete blood count and urinalysis were all within normal limits. The 24-hour urine protein content was normal and showed no evidence of amyloidosis. According to HLA tissue typing of the patient, HLA-A1, HLA-A2, HLA-B51, HLA-B44, HLA-BW4, and the HLA-B27 antigen were all negative.

Cervical spine $\mathrm{X}$-rays revealed flattening of the cervical lordosis with ankylosis and irregularity of the apophyseal joints at the C2-C5 level. Anterior and posterior syndesmophyte bridging with calcification of the spinal ligaments was observed on his thoracic spine radiographs. However, no radiological findings, except for flattening of the lumbar lordosis, were detected on the lumbar spine radiographs. The anteroposterior radiograph of the pelvis showed marked narrowing of the joint spaces and sclerosis on the acetabular surface of both hip joints. The computerized tomography (CT) scan of the sacroiliac joints revealed bilateral grade 2 sacroiliitis, according to the classical New York criteria (Figure 2).

He was diagnosed with coexisting BD and AS. We began treatment with sulfasalazine ( $2 \mathrm{~g} /$ day), colchicine (1.5 mg/day) and a nonsteroidal anti-inflammatory drug. Orthopedic consultation was obtained and total hip arthroplasty was recommended to the patient. The rehabilitation program included physical therapy and exercises addressed especially to his neck, low back and hips. At five months after treatment, no improvement had been achieved in his pain complaints or oral and genital ulcerations, and the BASDAl score was found to be 4.8 . The patient was then started on infliximab $(5 \mathrm{mg} / \mathrm{kg}$ ) treatment. Four weeks after the first infusion, oral and genital ulcerations had disappeared. Following the fifth infusion, the BASDAI score was found to be 3.5. The patient benefited well from the treatment with infliximab and achieved $90 \%$ pain relief.

\section{Discussion}

Behçet's disease is a chronic inflammatory disease involving several organs, such as the skin, mucous membrane, eye, joint, lung, and central nervous system. AS is a prototype of seronegative spondyloarthropathy and a chronic systemic inflammatory disease of the axial skeleton, mainly affecting the sacroiliac joints and spine $(1,2)$. Reports concerning the coexistence of these two diseases are found rarely in the literature. Dubost et al. (15) reported three cases of BD and AS coexistence among 11 patients with $B D$. This case had received a diagnosis of $B D$ before our consultation. Diagnosis of AS was not made before although the patient had complaints of inflammatory low back pain, morning stiffness and restriction in spinal movements for the previous two years.

He was positive for HLA-B5 antigen (Bw 51 split), which has been found to be associated with BD patients in Japanese, Turkish, and other Middle Eastern and Mediterranean populations (1). Cobellis et al. (16)

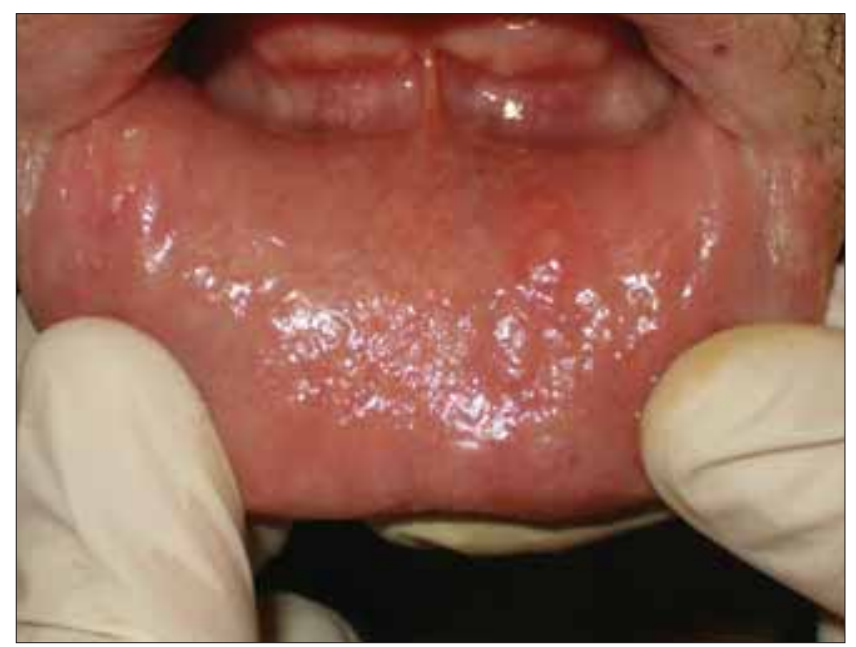

Figure 1. Typical oral aphthous ulcers in a common site, showing ulcers with inflammatory halo

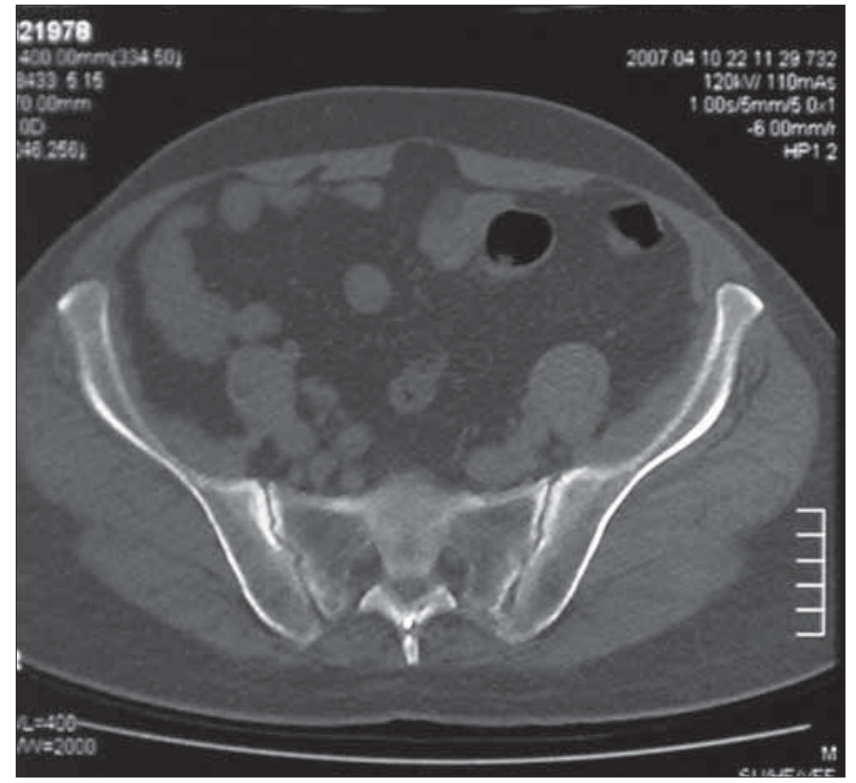

Figure 2. CT scan of sacroiliac joints showing bilateral grade 2 sacroiliitis (New York criteria) 
reported that frequency of BD might be increased in HLAB27-positive AS patients. Kallel et al. (8) noted that BD cases with negative HLA-B5 antigen had higher risk for AS. On the contrary, it was reported that HLA-B27 was found to be negative and HLA-B5 positive in the reports of Kotevoglu et al. (4) and Olivieri et al. (5), which is consistent with the findings of our case.

Our case described painful aphthous lesions in the oral region occurring three times a month, which would recover in two weeks. On physical examination, we observed painful aphthous lesions on the lower lip and upper palate (1). Lehner et al. (17) reported that the mucocutaneous involvement in BD was associated with HLA-B12. Our case was also positive for HLA-B12. Lesions in the genital region were localized on the glans penis and right inguinal line.

We found increased ESR and CRP levels, suggesting that the patient was in an active phase in terms of both AS and BD. The pathergy test of our patient was negative. Pathergy test-negative patients were also reported in other studies $(5,7)$. Ophthalmologic examination of the patient was normal. Similarly, Olivieri et al. (5) and Kallel et al. (8) reported their cases with no eye involvement.

Behçet's arthritis is usually mild and non-erosive and presents either as a monoarthritis or asymmetrical oligoarthritis. The most frequently involved joints were reported to be the knees, wrists, ankles, and elbows. The involvement of the distal interphalangeal joints, sacroiliac joints and spine is uncommon (18). Joint involvement occurs in up to $45-70 \%$ of patients, depending on the series (6).

Ankylosing spondylitis predominantly affects the sacroiliac joints and axial skeleton. Peripheral arthropathy occurs in approximately $20 \%$ to $30 \%$ of patients with AS (2). Our case had an axial involvement of AS but no peripheral arthritis suggesting BD. However, the patient described the symptoms of active arthritis in his knees that would occur several times a year. The hip joints, one of the most involved joints in AS, were extremely affected in our patient, leading to surgical indication.

Radiological changes in AS patients are seen rarely in the cervical region compared to thoracic and lumbar regions (2). In contrast, the radiological changes of our case were more prominent in the cervical and thoracic regions, and no characteristic radiological findings of AS were observed in the lumbar region. Researchers have reported that cervical involvement could be more prominent in female patients $(4,5)$. Inconsistent with this data, our patient was male, but radiological change in his cervical spine was prominent. The CT scan of the sacroiliac joints showed bilateral grade 2 sacroiliitis. Olivieri et al. (5) found sacroiliitis in $30 \%$ of patients with BD. In parallel with these clinical reports, we also agree that sacroiliitis in BD should not be considered as a characteristic feature of the disease. Similar to our case, AS may coexist with BD. Therefore, this coexistence should be kept in mind.
Tumor necrosis factor (TNF) -alpha blocking agents are commonly used in treatment regimens for AS. However, the use of these biological agents in BD is not as common as in AS. Recently, it was emphasized that TNF-alpha molecule may have a significant role in the pathogenesis of BD (12). Moreover, infliximab was reported to be a new, safe and effective agent in the treatment of BD (11). Our patient also benefited well from this treatment regimen. Infliximab may be an alternative therapeutic option not only in AS patients but also in BD patients who are resistant to other drugs.

In conclusion, though it is rare, the coexistence of $B D$ and AS may be encountered in clinical practice, and this condition should be kept in mind. If there is a resistance to the conservative treatments, TNF-alpha blocking agents may be an alternative therapeutic option in these diseases.

\section{Conflict of Interest}

No conflict of interest declared by the authors.

\section{References}

1. Conn DL, Hunder GG, O'Duffy JD. Behcet's disease. In: Kelley WN (ed). Textbook of Rheumatology, 4th edition. Philadelphia: Elsevier Saunders 2005: 1097-9.

2. Moll MH, Halslock I, Wright V. Seronegative spondyloarthritis. In: Scott JT (ed). Copeman's Textbook of Rheumatic Diseases, 5th edition. Edinburgh: Churchill Livingstone 1992: 578-88.

3. Borman P, Bodur H, Ak G, Bostan EE, Barça N. The coexistence of Behçet's disease and ankylosing spondylitis. Rheumatol Int 2000; 19: 195-8.

4. Kotevoglu N. Coexistence of ankylosing spondylitis and Behcet's disease. Two cases with atypical presentation and course. Scand J Rheumatol 2003; 32: 184-5.

5. Olivieri I, Gemignani G, Busoni F, Pecori F, Camerini E, Trippi $D$, et al. Ankylosing spondylitis with predominant involvement of the cervical spine in a woman with Behcet's syndrome. Ann Rheum Dis 1988; 47: 780-3.

6. Etaouil N, Benyahya E, Bennis R, Mkinsi O. Ankylosing spondylitis and Behçet's disease in combination. Two case reports. Joint Bone Spine 2002; 69: 96-8.

7. Tosun M, Uslu T, Ibrahim Imamoglu H, Bahadir S, Erdolu S, Guler M. Coexisting ankylosing spondylitis and Behcet's disease. Clin Rheumatol 1996; 15: 619-20.

8. Kallel MH, Bejia I, Fournie B, Fournie A. Behcet syndrome with ankylosing spondylitis. Rev Rhum Engl Ed 1995; 62: 295-9.

9. Cimen OB, Sahin G, Biçer A, Erdogan C. Behçet's syndrome coexisting with clinically occult ankylosing spondylitis. South Med J 2002; 95: 1355-6.

10. Baraliakos X, Listing J, Brandt J, Haibel H, Rudwaleit M, Sieper J, et al. Radiographic progression in patients with ankylosing spondylitis after 4 yrs of treatment with the antiTNF-alpha antibody infliximab. Rheumatology (Oxford) 2007; 46: 1450-3.

11. Lee JH, Kim TN, Choi ST, Jang BI, Shin KC, Lee SB, et al. Remission of intestinal Behçet's disease treated with antitumor necrosis factor alpha monoclonal antibody (Infliximab). Korean J Intern Med 2007; 22: 24-7.

12. Kamoun M, Chelbi H, Houman MH, Lacheb J, Hamzaoui K. Tumor necrosis factor gene polymorphisms in Tunisian 
patients with Behcet's disease. Hum Immunol 2007; 68 201-5.

13. International Study Group for Behçet's disease. Criteria for diagnosis of Behcet's disease. Lancet 1990; 335: 1078-80.

14. Beiran I, Scharf J, Dori D, Miller B. A change in ocular involvement in a patient suffering from ankylosing spondylitis and Behcet's disease. Eur J Ophthalmol 1995; 5 192-4.

15. Dubost JJ, Sauvezie B, Galtier B, Bussière JL, Rampon S Behcet's syndrome and ankylosing spondylarthritis. Rev Rhum Mal Osteoartic 1985; 52: 457-61.
16. Cobellis L, Pecori E, Rigatti F, Rotondi M, Scaffa C, De Lucia $\mathrm{E}$, et al. Therapeutic alternatives in Behçet's syndrome. Clin Exp Obstet Gynecol 2007; 34: 151-3.

17. Lehner T, Welsh KI, Batchelor JR. The relationship of HLA-B and DR phenotypes to Behcet's syndrome, recurrent oral ulceration and the class of immune complexes. Immunology 1982; 47: 581-7.

18. Yurdakul S, Yazici $H$, Tüzün $Y$, Pazari $H$, Yalcin $B$, Altac M, et al. The arthritis of Behçet's disease: a prospective study. Ann Rheum Dis 1983; 42: 505-15. 